\title{
Glycated lysine residues: A marker for non-enzymatic protein glycation in age-related diseases
}

\author{
Nadeem A. Ansari*, Moinuddin and Rashid Ali \\ Department of Biochemistry, J N Medical College, AMU, Aligarh-02, India
}

\begin{abstract}
Nonenzymatic glycosylation or glycation of macromolecules, especially proteins leading to their oxidation, play an important role in diseases. Glycation of proteins primarily results in the formation of an early stage and stable Amadori-lysine product which undergo further irreversible chemical reactions to form advanced glycation endproducts (AGEs). This review focuses these products in lysine rich proteins such as collagen and human serum albumin for their role in aging and age-related diseases. Antigenic characteristics of glycated lysine residues in proteins together with the presence of serum autoantibodies to the glycated lysine products and lysine-rich proteins in diabetes and arthritis patients indicates that these modified lysine residues may be a novel biomarker for protein glycation in aging and age-related diseases.
\end{abstract}

Keywords: Lysine, Glycation, Amadori products, AGEs, autoantibodies, diabetes, biomarker

\section{Introduction}

A non-enzymatic glycosylation or Maillard reaction of proteins primarily takes place at $\varepsilon$-amino groups of lysine or their free amino groups. The side chains of arginine, histidine, tryptophan and cysteine residues are the other sites for glycation [48]. Amadori-modified proteins, an early glycation product, undergo further reactions through a number of pathways and giving rise to advanced glycation end products (AGEs) $[73,76]$. Reactive carbonyl species (RCS), such as glyoxal, formed from autoxidative degradation of glucose and from other metabolic activities, react with lysine residues of proteins to form $\mathrm{N}^{\varepsilon}$-carboxymethyllysine (CML), a nonfluorescent and non-cross linking AGE [15]. CML is also formed by oxidative degradation of Amadori products [50]. A scheme for the formation of Amadori products and AGEs in glycated proteins with their role in diseases has been shown in Fig. 1.

Glycation and free radical theories of aging are used to explain the mechanism of aging [35]. According

* Corresponding author: Department of Biochemistry, Institute of Medical Sciences, Banaras Hindu University, Varanasi-221005, India. Tel.: +91 9760228860; E-mail: anadeem1@rediffmail.com. to glycation theory, cross linking and denaturation of proteins caused by glycation are the main factors for early aging induced alteration in tissues and blood vessels $[44,45]$. A recent study has put forward the alterations caused by biochemical side reactions as the essential mechanism of aging [83]. In this review, we shall discuss the evidences that support the role of glycated (AGE and Amadori products) lysine residues of proteins in aging and age-related diseases. Antigenicity of the glycated proteins and presence of autoantibodies against native and modified proteins, in age associated diseases, will be considered for the discussion.

\section{Glycated lysine-rich proteins and their involvement in age-related diseases}

There have been investigations on a number of proteins subjected to glycation [9]. Some of the important proteins were crystallin proteins [71], hemoglobin [13], proteins of erythrocyte membrane [42], insulin [19], human serum albumin (HSA) [67], high and lowdensity lipoproteins (HDL and LDL) [34], IgG [32, 39], IgM [41], collagen [23], histones [14,82]. Majority of these proteins were glycated through their ly- 


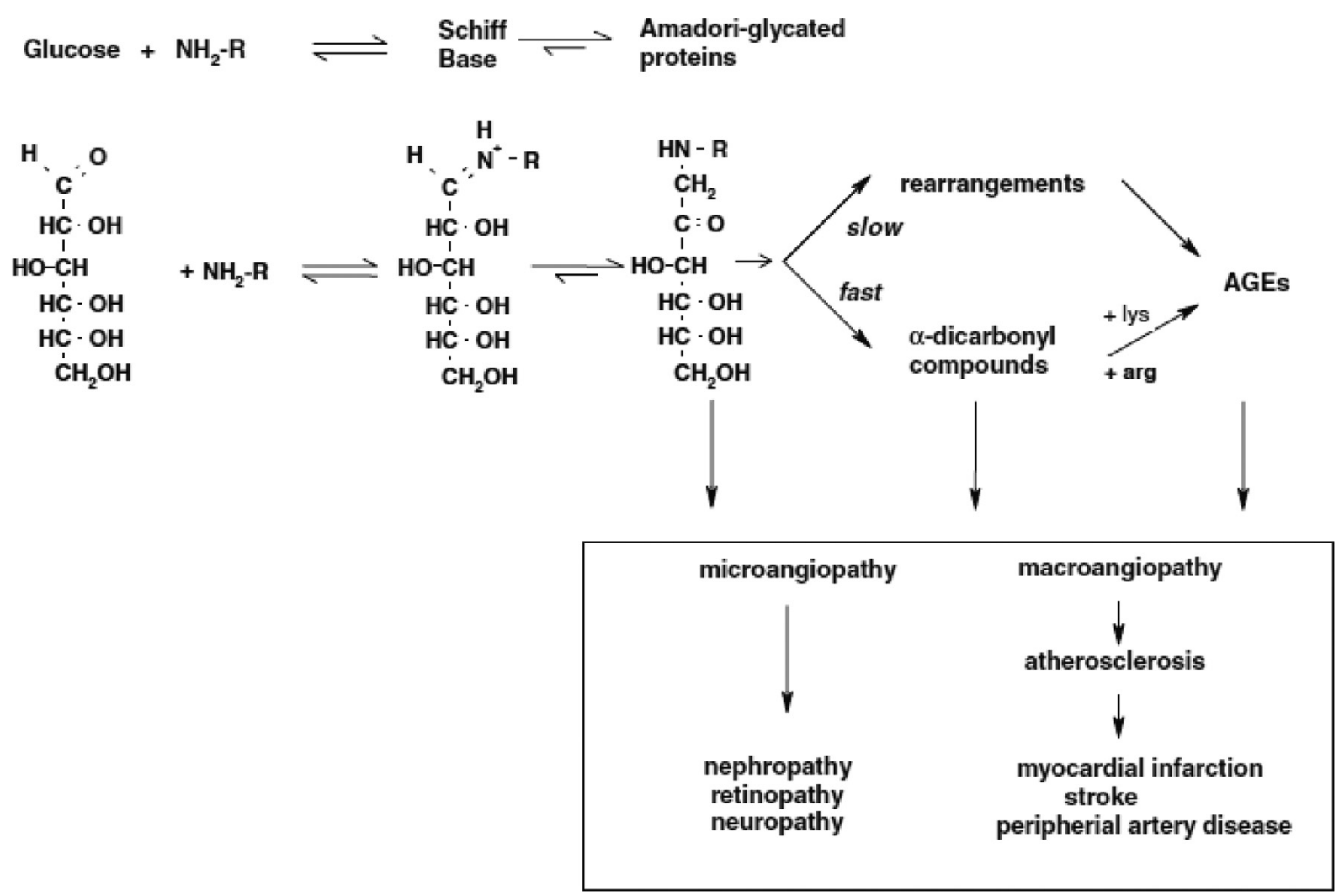

Fig. 1. A scheme for formation of glycated proteins via lysine and arginine residues and their role in vascular complications (NH2-R is an amino group of a protein) (adapted from Schalkwijk and Miyata 2010).

sine residues. A recent investigation has found that in presence of cysteine residues, lysine residues react with RCS while arginine residues were protected from the reaction but in absence of cysteine the reaction mechanism was reversed [63]. Examples of glycated proteins (lysine rich) and products that are formed during the process of aging and age-related diseases have been summarized in Table 1.

Specific lysine residues in hemoglobin and human serum albumin have been identified as preferential sites of glycation in vivo [80]. In hemoglobin, the most reactive lysine residues appeared to be located to carboxylate groups in the primary or three-dimensional structure of the protein, while in albumin the reactive lysine is adjacent to another lysine residue in the primary sequence. In human body, histone proteins of the nucleus are richest in lysine and are modified to form CML [15]. Histones $\mathrm{H} 3$ and H2B were found to contain highest content of CML relative to lysine while histone $\mathrm{H} 1$ was the most highly carboxymethylated protein on a total protein basis. Glyceraldehyde induced Amadori modification of hemoglobin was reported by Acharya and Manning [1] and synthetic peptides were synthesized with lysine residues as the specific site for Amadori modification [22].

AGE modified proteins have been associated with aging and diabetes [53,78]. Apart from diabetes mellitus, AGEs are continuously linked to other age-related diseases like rheumatoid arthritis (RA) [16,40,43], Alzheimer [3,11]. Recent investigations have shown the role of AGEs, particularly CML, in aging and age associated risk of kidney damage and cardiovascular disease $[26,65]$. CML has been also detected in breast cancer $[10,79]$ and plasma protein CML serves as a biomarker for age-related macular degeneration [52]. Glucosepane, a lysyl-arginine cross-link for collagen, is formed under non-oxidative conditions and is linked with aging and diabetes $[46,66]$ while 2-Ammonio-6(3-oxidopyridinium-1-yl)hexanoate (OP-lysine), identified as AGE product of lysine in aged human lenses, is a potential risk factor for cataract [8].

Amadori- and AGE-modified histones were detected in liver cells of diabetic patients [29,30] whereas a number of Amadori-modified plasma proteins (viz. immunoglobulin heavy-chain constant regions) have been identified in type 2 diabetic patients [28]. Albumin 
Table 1

Examples of proteins involving lysine residues for glycation and of glycated lysine product in age-related processes/diseases

\begin{tabular}{|c|c|c|}
\hline Proteins & Process/Disease & References \\
\hline Collagen & Aging, Diabetes & $\begin{array}{l}\text { Dunn et al. 1991, } \\
\text { Sjoberg and Bulterijs, } 2009\end{array}$ \\
\hline HDL \& LDL & Aging and Diabetes & Kirstein et al. 1990 \\
\hline CML & $\begin{array}{l}\text { Diabetes mellitus, Aging, } \\
\text { Atherosclerosis, Cancer }\end{array}$ & $\begin{array}{l}\text { Schleicher et al. } 1997 \text {, } \\
\text { Bachmeier et al. 2008, } \\
\text { Semba et al. 2009, } \\
\text { Ni et al., } 2009\end{array}$ \\
\hline $\operatorname{IgG}$ & $\begin{array}{l}\text { Diabetes mellitus and } \\
\text { its complications, } \\
\text { Rheumatoid arthritis }\end{array}$ & $\begin{array}{l}\text { Kalia et al. } 2004, \\
\text { Newkirk et al. } 2003\end{array}$ \\
\hline $\operatorname{IgA}$ & $\begin{array}{l}\text { Diabetes mellitus and } \\
\text { its complications }\end{array}$ & Kalia et al. 2004 \\
\hline $\operatorname{IgM}$ & $\begin{array}{l}\text { Diabetes mellitus and } \\
\text { its complications }\end{array}$ & Kalia et al. 2004 \\
\hline HSA & $\begin{array}{l}\text { Diabetes mellitus and } \\
\text { its complications, } \\
\text { Alzheimer }\end{array}$ & $\begin{array}{l}\text { Schalkwijk et al. 1999, } 2002 \\
\text { Bouma et al. 2003, } \\
\text { Cohen et al. } 2010\end{array}$ \\
\hline Histones & Diabetes mellitus & $\begin{array}{l}\text { Jobst et al. 1991, } \\
\text { Jobst and Lakattos 1996, } \\
\text { Cervantes-Laurean et al., } 2005\end{array}$ \\
\hline Hemoglobin & $\begin{array}{l}\text { Diabetes mellitus and } \\
\text { its complications }\end{array}$ & Kalia et al. 2004 \\
\hline Crystallins & $\begin{array}{l}\text { Diabetes mellitus, } \\
\text { Lens opacity }\end{array}$ & $\begin{array}{l}\text { Akhtar et al. } 1999 \text {, } \\
\text { Ranjan et al. } 2006\end{array}$ \\
\hline
\end{tabular}

bearing Amadori compounds was associated with early nephropathy and with retinopathy in type 1 diabetic patients [59,60]. Glycated immunoglobulins (IgG, $\operatorname{Ig} \mathrm{A}, \operatorname{IgM})$ and glycated hemoglobin have been found in increased level in both type 1 and 2 diabetic patients with nephropathy as compared to the patients without any complications [31]. The investigations resulted in a detailed study for Amadori product in diabetes complications [47]. Previous reports on poly-L-lysine, a homopolymer of lysine residues with a large number of free $\varepsilon$-amino groups, were restricted to characterization of their browning products or AGEs [37,38]. In our investigation, the polypeptide was used to elaborate the role of Amadori lysine adducts in diabetes mellitus [5, $6]$.

\section{Antigenicity of glycated lysine residues in proteins}

Anti-hexitol lysine IgG, a polyclonal antibody raised in rabbits, was used to detect Amadori modified proteins in tissues of normal and diabetic rats [49] while Schalkwijk et al. [60] have used anti-Amadori albumin antibodies to recognize cyclic form (pyranose or furanose) of the Amadori product. Reactive carbonyl species, such as glyoxal, modify lysine and arginine residues of proteins but their reaction products (AGEs) were detected by antibodies specific for sugar-derived AGEs [58]. In our study, antigenicity of glycated lysine residues in proteins was probed by immunization of rabbits with glycated poly-L-lysine [5]. Glycated poly-L-lysine was found to be highly antigenic and the antigen exhibited a high degree of specificity for the induced antibodies. The study reflects that despite its homogeneous nature and lacking aromatic group, lysine polypeptide got the characteristic of an antigen when conjugated with glucose. The induced antibodies showed polyspecificity as they recognized similarly modified lysine rich proteins (IgG, HSA and histones). This is the indication towards generation of common epitopes in the glycated lysine residues.

\section{Serum autoantibodies against oxidized and glycated proteins in age-related diseases}

A detailed study has been done for oxidatively modified autoantigens in autoimmune diseases [36]. Autoantibodies to native proteins such as GAD-65 and HSA are present in diabetes, but the antibodies to GAD65 and other proteins have been reported both in patients with autoimmune diseases and in patients with cancer [12]. It has been shown that oxidized low- 
Table 2

Activity of autoantibodies to glycated IgG in type 1 diabetes patients (Adapted from Rasheed et al. 2009)

\begin{tabular}{|c|c|c|c|c|c|c|c|c|c|c|c|}
\hline \multirow{3}{*}{$\begin{array}{c}\text { DM } \\
\text { Patients }\end{array}$} & \multirow[t]{3}{*}{$\begin{array}{c}\text { Age } \\
\text { (Year) }\end{array}$} & \multirow[t]{3}{*}{$\begin{array}{c}\text { Sex } \\
(M / F)\end{array}$} & \multirow{3}{*}{$\begin{array}{l}\text { Blood } \\
\text { Glucose } \\
(\mathrm{mg} / \mathrm{dl})\end{array}$} & \multirow[t]{3}{*}{$\mathrm{Hb} \mathrm{A}_{1 \mathrm{C}}$} & \multirow[t]{3}{*}{$\begin{array}{l}\text { Smoking } \\
\text { Duration }\end{array}$} & \multicolumn{2}{|c|}{$\begin{array}{l}\text { Detection of Anti- } \\
\text { AGE-IgG Antibodies }\end{array}$} & \multicolumn{2}{|c|}{$\begin{array}{c}\text { Detection of } \\
\text { Anti-IgG Antibodies }\end{array}$} & \multicolumn{2}{|c|}{$\begin{array}{l}\text { Cabonyl Contents } \\
\text { (nmol/mgprotein) }\end{array}$} \\
\hline & & & & & & $A_{410}$ & MP1 & $A_{410}$ & MP1 & \multirow{2}{*}{$\begin{array}{l}\text { DM se- } \\
\text { rum }\end{array}$} & \multirow[t]{2}{*}{ DM-IgG } \\
\hline & & & & & & AGE-IgG & & IgG & & & \\
\hline 1 & 60 & M & 440 & 8.9 & 32 & 0.92 & 65.1 & 0.49 & 25.5 & 3.5 & 1.3 \\
\hline 2 & 61 & $\mathrm{M}$ & 439 & 8.8 & 34 & 0.93 & 64.3 & 0.48 & 27.2 & 3.6 & 1.1 \\
\hline 3 & 61 & $\mathrm{M}$ & 435 & 9.2 & 36 & 0.94 & 64.4 & 0.53 & 27.2 & 3.5 & 1.2 \\
\hline 4 & 60 & $\mathrm{M}$ & 415 & 8.2 & 34 & 0.93 & 62.2 & 0.54 & 21.1 & 3.3 & 1.1 \\
\hline 5 & 57 & $\mathrm{M}$ & 404 & 8.8 & 33 & 0.89 & 57.4 & 0.46 & 32.3 & 3.1 & 1.0 \\
\hline 6 & 59 & $\mathrm{M}$ & 415 & 8.5 & 30 & 0.81 & 54.2 & 0.43 & 29.4 & 3.5 & 1.2 \\
\hline 7 & 59 & M & 405 & 7.8 & 29 & 0.90 & 53.3 & 0.37 & 30.2 & 3.0 & 1.1 \\
\hline 8 & 41 & $\mathrm{M}$ & 395 & 7.4 & 16 & 0.89 & 51.5 & 0.36 & 29.0 & - & - \\
\hline 9 & 40 & $\mathrm{M}$ & 373 & 8.2 & 13 & 0.89 & 52.6 & 0.37 & 35.8 & - & - \\
\hline 10 & 40 & $\mathrm{M}$ & 372 & 7.8 & 15 & 0.85 & 49.0 & 0.35 & 38.4 & - & - \\
\hline 11 & 39 & $\mathrm{M}$ & 365 & 8.1 & 9 & 0.84 & 43.8 & 0.31 & 33.0 & - & - \\
\hline 12 & 34 & $\mathrm{M}$ & 324 & 7.1 & - & 0.81 & 39.4 & 0.31 & 30.2 & - & - \\
\hline 13 & 45 & F & 329 & 7.3 & - & 0.71 & 41.4 & 0.37 & 31.3 & 2.6 & 0.9 \\
\hline 14 & 25 & F & 372 & 8.5 & - & 0.79 & 47.8 & 0.42 & 20.1 & - & - \\
\hline 15 & 24 & F & 364 & 8.0 & - & 0.77 & 37.1 & 0.41 & 31.8 & 2.9 & 1.0 \\
\hline 16 & 58 & F & 390 & 8.6 & - & 0.92 & 60.2 & 0.51 & 27.2 & 3.0 & 1.2 \\
\hline 17 & 43 & F & 352 & 8.8 & - & 0.90 & 43.1 & 0.37 & 20.1 & 2.7 & 0.8 \\
\hline 18 & 35 & F & 342 & 7.2 & - & 0.88 & 42.2 & 0.38 & 28.1 & - & - \\
\hline 19 & 30 & F & 340 & 7.3 & - & 0.86 & 37.1 & 0.39 & 19.4 & - & - \\
\hline Mean $\pm S D$ & $45.8 \pm 13.0$ & $12 \mathrm{M} / 7 \mathrm{~F}$ & $383 \pm 36.6$ & $8.13 \pm 0.65$ & $25.5 \pm 10.1$ & $0.85 \pm 0.06^{\circ}$ & $50.8 \pm 9.5^{* *}$ & $0.51 \pm 0.07$ & $28.3 \pm 5.3$ & $3.15 \pm 0.35^{\#}$ & $1.1 \pm 0.15^{ \pm \#}$ \\
\hline $\begin{array}{c}\text { Control } \\
\text { Mean } \pm \text { SD }\end{array}$ & $\begin{array}{c}42.0 \pm 15.0 \\
(\mathrm{n}=22)\end{array}$ & $\begin{array}{l}14 \mathrm{M} / 8 \mathrm{~F} \\
(\mathrm{n}=22)\end{array}$ & $\begin{array}{l}115 \pm 7.5 \\
(\mathrm{n}=22)\end{array}$ & $\begin{array}{l}4.6 \pm 0.5 \\
(n=22)\end{array}$ & $\begin{array}{c}22.1 \pm 6.4 \\
(\mathrm{n}=22)\end{array}$ & $\begin{array}{c}0.26 \pm 0.04 \\
(\mathrm{n}=22)\end{array}$ & $\begin{array}{c}14.2 \pm 6.3 \\
(\mathrm{n}=22)\end{array}$ & $\begin{array}{c}0.23 \pm 0.04 \\
(\mathrm{n}=22)\end{array}$ & $\begin{array}{c}16.2 \pm 4.3 \\
(\mathrm{n}=22)\end{array}$ & $\begin{array}{c}\mathrm{NH} \text { serum } \\
2.28 \pm 0.25 \\
(\mathrm{n}=11)\end{array}$ & $\begin{array}{c}\text { NH-IgG } \\
0.60 \pm 0.18 \\
(\mathrm{n}=11)\end{array}$ \\
\hline
\end{tabular}

DM: type 1 diabetes mellitus; M: male; F: female; $n$ : number of samples tested; DM-serum: serum from DM patients; DM-IgG: IgG from DM patients; NH-serum: serum from normal human; NH: normal human; NH-IgG: IgG from normal humans; $\mathrm{A}_{410}$ : absorbance at $410 \mathrm{~nm}$ calculated by direct binding ELISA; MPI : maximum percent inhibition at $20 \mu \mathrm{g} / \mathrm{ml}$ of inhibitor concentration calculated by competitive inhibition ELISA. " $\mathrm{p}<0.05$ vs. $A 410$ (native IgG); ${ }^{p}<0.001$ vs. MPI (IgG); ${ }^{*}<0.05$ vs. NH-serum; ${ }^{p}<0.05$ vs. NH-IgG.

density lipoproteins [20] and hydroxyl radical modified GAD proteins $[33,75]$ were involved in production of autoantibodies in diabetic patients. Low levels of autoantibodies to amyloid beta peptide or oxidized LDL were associated with aging and risk factor for developing Alzheimer's disease and atherosclerosis [70, 81].
Proteins modified by glycation and glycoxidation in vivo, serves as immunological epitopes leading to the production autoantibodies. Autoantibodies against AGE-HSA were detected in diabetic patients [76] whereas autoantibodies against glycated crystallins have been found in diabetic rats and cataract patients in the age group of 40-60 years [54,55]. Levels of these 
autoantibodies were significantly higher at every stage when compared to their healthy controls. The concentration of antibodies was determined by antibody capture assay and that of antigen by non-competitive enzyme linked immunosorbent assay (ELISA). The studies of Shibayama et al. [68] and Araki et al. [7] have shown that the activity of autoantibodies to AGE especially CML increased with the duration of diabetic states. Patients with renal failure and those of diabetic nephropathy had a higher autoantibody activity than that in normal subjects or diabetic patients without any complication. They have put forward that immunocomplexes of autoantibody and AGE, accumulated in glomeruli, contribute to the pathogenesis of diabetes. Another study has shown that monoclonal antibodies against glycated albumin inhibit diabetic nephropathy [17]. Progression of diabetes to diabetic complications was found to be associated with the number of antibodies rather than a single antibody [72]. Although it remains unclear from the studies towards the role played by autoantibodies to glycated proteins in pathogenesis of the diseases, the autoantibodies can be used for prediction of autoimmune and age related diseases [64].

A previous investigation has found serum autoantibodies to AGE-IgG to the extent of $49 \%$ in rheumatoid factor positive RA patients [51]. Our investigation on role of glycated IgG in diabetes, revealed a binding of $61 \%$ of autoantibodies of type 1 diabetic patients to AGE-IgG as compared to the native form [57]. Reactivity of these serum autoantibodies to glycated $\mathrm{IgG}$ in the patients has been presented in Table 2. Sera of diabetic patients were probed for the presence of antibodies against glycated lysine residues with the use of glycated poly-L-lysine. Amadori-rich glycated polyL-lysine was recognized by $64 \%$ of serum antibodies from diabetic patients (both type $1 \& 2$ ) [5]. The higher binding to glycated poly-L-lysine by the antibodies in diabetic patients suggests the involvement of glycated lysine residues in the production of autoantibodies in these patients.

\section{Inhibition of glycated protein}

The role of lysine residues in the glycation of proteins has been substantiated by the recent investigations showing inhibition of protein glycation by lysine [27,69]. Studies on several other glycation inhibitors have shown promising results in experimental animal models and some of them like GLY-
230 (2-[3-chlorophenylamino]phenylacetic acid) decrease glycated albumin in diabetic patients while others like ALT-711 (3-phenacyl-4,5-dimethylthiazolium chloride), the AGE-cross-link breaker is in advanced clinical studies in humans [61]. The use of aminoguanidine is discontinued due to its side effect in humans but recently the use of pyridoxamine is also compromised [74]. Other studies have suggested that soluble receptor for AGE (sRAGE) or RAGE antagonist could be a future therapeutic target for inhibiting glycation [24]. The recent focus on bioactive substances of caffeic and chlorogenic acid [25] that are found in herbal mate tea and S-allyl cysteine in aged garlic extract [2] have shown positive effect towards inhibiting AGE formation.

The effect of glycation on lysine rich proteins and their involvement in aging and age-related diseases has been reviewed. The evidences support antigenicity of the glycated lysine residues in vivo with observation of autoantibodies against the glycated proteins in diabetes and RA patients. This could be due to protection of the modified proteins from proteolytic breakdown and its recognition as a foreign molecule by the immune system. A greater understanding of the regulation of glycated lysine products, especially Amadori products, in aging may play an important role in preventing the risk of age-related diseases. Thus, autoantibodies to glycated lysine rich proteins pose a marker for future age related diseases in presently healthy individuals.

\section{Acknowledgements}

We are thankful to the staff members of library of Aligarh Muslim University, India for support towards collecting literature of the study.

\section{Conflict of interest statement}

The authors declare that there are no conflicts of interest.

\section{References}

[1] A.S. Acharya and J.M. Manning, Amadori rearrangement of glyceraldehyde-hemoglobin Schiff base adducts, Journal of Biological Chemistry 255 (1980), 7218-7224.

[2] M.S. Ahmad, M. Pischetsrieder and N. Ahmed, Aged garlic extract and S-allyl cysteine prevent formation of advanced glycation endproducts, European Journal of Pharmacology 56 (2007), 32-38. 
[3] N. Ahmed, U. Ahmed, P.J. Thornalley, K. Hager, G. Fleischer and G. Munch, Protein glycation, oxidation and nitration adduct residues and free adducts of cerebrospinal fluid in Alzheimer's disease and link to cognitive impairment, Journal of Neurochemistry 92 (2005), 255-263.

[4] N.J. Akhtar, T. Sun and J. Liang, Conformational study of $\mathrm{N} \varepsilon$ (carboxymethyl)lysine adducts of recombinant $\alpha$-crystallins, Current Eye Research 18 (1999), 270-276.

[5] N.A. Ansari, Moinuddin, Alam K, Ali A. Preferential recognition of Amadori-rich lysine residues by serum antibodies in diabetes mellitus: Role of protein glycation in the disease process, Human Immunology 70 (2009), 417-424.

[6] N.A. Ansari, Moinuddin. Identification of Amadori-modified immunoglobulin $\mathrm{G}$ in type 2 diabetic patients with secondary complications, IUBMB Life 61(3) (2009), 309-310.

[7] N. Araki, R. Shibayama, Y. Ejima, R. Nagai, T. Araki, H. Saya and S. Horiuchi, Study of autoantibodies against advanced glycation endproducts of the Maillard reaction, International Congress Series 123 (2001), 49-58.

[8] O.K. Argirov, B. Lin and B.J. Ortwert, 2-Ammonio-6-(3oxidopyridinium-1-yl)hexanoate (OP-lysine) is a newly identified advanced glycation end product in cataractous and aged human lenses, Journal of Biological Chemistry 8 (2004), 6487-6496.

[9] D.A. Armbruster, Fructosamine: structure, analysis and clinical usefulness, Clinical Chemistry 33 (1987), 2153-2163.

[10] B.E. Bachmeier, A.G. Nerlich, H. Rohrbach, E.D. Schleicher and E.D. Friess, Maillard products as biomarkers in cancer, Annals of the New York Academy of Sciences 1126 (2008), 283-287.

[11] B. Bouma, L.M.J. Kroon-Batenburg, Y. Wu, B. Brunjes, G. Posthuma, O. Kranenburg, P.G. Groot, E.E. Voest and M.F.B.G. Gebbink, Glycation induces formation of amyloid cross- $\beta$ structure in albumin, Journal of Biological Chemistry 278(43) (2003), 41810-41819.

[12] R. Bei, L. Masuelli, C. Palumbo, M. Modesti and A. Modesti, A common repertoire of autoantibodies is shared by cancer and autoimmune disease patients: Inflammation in their induction and impact on tumor growth, Cancer Letters 281 (2009), 8-23.

[13] H.F. Bunn, R. Shapiro, M. McManus, L. Garlick, M.J. McDonald, P.M. Gallop and K.H. Gabbay, Structural heterogeneity of human hemoglobin A due to non-enzymatic glycosylation, Journal of Biological Chemistry 254 (1979), 3892-3898.

[14] D. Cervantes-Laurean, E.L. Jacobson and M.K. Jacobson, Glycation and Glycoxidation of histones by ADP-ribose, Journal of Biological Chemistry 271 (1996), 10461-10469.

[15] D. Cervantes-Laurean, M.I. Roberts and E.L. Jacobson, Nuclear proteasome activation and degradation of carboxymethylated histones in human keratinocytes following glyoxal treatment, Free Radical Biology and Medicine 38 (2005), 786-795.

[16] J.R. Chen, S. Takahashi, M. Suzuki, K. Kushida, S. Miyamoto and T. Inoue, Pentosidine in synovial fluid in osteoarthritis and rheumatoid arthritis: relationship with disease activity in rheumatoid arthritis, Journal of Rheumatology 25 (1998), 2440-2444.

[17] M.P. Cohen, E. Hud and V.Y. Wu, Amelioration of diabetic nephropathy by treatment with monoclonal antibodies against glycated albumin, Kidney Intenational 45 (1994), 1673-1679.

[18] M.P. Cohen, E. Hud and E. Shea, Rate of formation of glycated albumin revisited and clinical implications, Journal of Diabetes and Metabolism 1 (2010), 102, (doi:10.4172/21556156.1000102).

[19] R. Dolhofer and O.H. Weiland, Preparation and biological properties of glycosylated albumin, FEBS Letters 100 (1979),
$133-136$

[20] A. Dotevall, J. Hulthe, A. Rosengren, O. Wiklund and O. Wilhelsen, Autoantibodies against oxidized low-density lipoprotein and C-reactive protein are associated with diabetes and myocardial infarction in women, Clinical Science 101 (2001), 523-531.

[21] J.A. Dunn, D.R. McCance, S.R. Thorpe, T.J. Lyons and J.W. Baynes, Age-dependent accumulation of $\mathrm{N}_{-} \varepsilon$ (Carboxymethy1)lysine and $\mathrm{N}_{-}{ }^{\varepsilon}$ (Carboxymethy1)hydroxylysine in human skin collagen, Biochemistry 30 (1991), 1205-1210.

[22] A. Frolov, D. sdzxc Singer and R. Hoffmann, Site-specific synthesis of Amadori-modified peptides on solid phase, Journal of Peptide Science 12 (2006), 389-395.

[23] M.-X. Fu, K.J. Wells-knecht, J.A. Blackledge, T.J. Lyons, S.R. Thorpe and J.W. Baynes, Glycation, glycoxidation and crosslinking of collagen by glucose. Kinetics, mechanisms, and inhibition of late stages of the Maillard reaction, Diabetes 43 (1994), 676-683.

[24] S.Y. Goh and M.E. Cooper, Clinical review: the role of advanced glycation endproducts in progression and complications of diabetes, Journal of Clinical Endocrinology and Metabolism 93 (2008), 1143-1152.

[25] A. Gugliucci, D.H.M. Bastos, J. Schulze and M.F.F. Souza, Caffeic and cholorogenic acids in Ilex paraguariensis are the main inhibitors of AGE generation by methylglyoxal in model proteins, Fitoterapia 80 (2009), 339-344.

[26] M. Hamelin, C. Borot-Laloi, B. Friguet and $\mathrm{H}$. Bakala, Increased level of glycoxidation product $N^{\varepsilon_{-}}$ (carboxymethy1)lysine in rat serum and urine proteins with aging: Link with glycoxidative damage accumulation in kidney, Archives of Biochemistry and Biophysics 411 (2003), 215-222.

[27] A. Jafarnejad, S.J. Bathaie, M. Nakhjavani, M.J. Hassan and M.J. Banasadegh, The improvement effect of L-lysine as a chemical chaperone on STZ-induced diabetic rats, protein structure and function, Diabetes/Metabolism Research and Reviews 24 (2008), 64-73.

[28] A. Jaleel, P. Halvatsiotis and B. Williamson, Identification of Amadori-modified plasma proteins in type 2 diabetes and the effect of short-term intensive insulin treatment, Diabetes Care 28 (2005), 645-652.

[29] K. Jobst, A. Lakattos and A. Horvath, Glycohistones in diabetic human liver, Clinica Chimica Acta 200 (1991), 231-232.

30] K. Jobst and K. Lakattos, The liver cell histones of diabetic patients contain AGEs which may be lipofuscin components, Clinica Chimica Acta 256 (1996), 203-204.

[31] K. Kalia, S. Sharma and S. Mistry, Non-enzymatic glycosylation of immunoglobulins in diabetic nephropathy, Clinica Chimica Acta 347 (2004), 169-176.

[32] H. Kaneshige, Nonenzymatic glycosylation of serum IgG and its effect on antibody activity in patients with diabetes mellitus, Diabetes 36 (1987), 822-828.

[33] M.W.A. Khan, S. Sherwani, W.A. Khan and Ali R. Moinuddin, Characterization of hydroxyl radical modified GAD65: A potential autoantigen in type 1 diabetes, Autoimmunity 42 (2009), 150-158.

[34] M. Kirstien, J. Brett, S. Radoff, S. Ogawa, D. Stern and $\mathrm{H}$. Vlassara, Advanced protein glycosylation induces transendothelial human monocyte chemotaxis and secretion of platelet-derived growth factor: role in vascular disease of diabetes and aging, Proceedings of the National Academy of Sciences USA 87 (1990), 9010-9014.

[35] B.S. Kristal and B.P. Yu, An emerging hypothesis: synergistic induction of aging by free radicals and Maillard reactions, $J_{o-}$ 
urnal of Gerontology 47(4) (1992), B107-B114.

[36] B.T. Kurien and R.H. Scofield, Autoimmunity and oxidatively modified autoantigens, Autoimmun Rev 7 (2008), 567-573.

[37] A. Lapolla, C. Gerhardinger, L. Baldo, D. Fedele, D. Favretto, R. Seraglia et al., Pyrolysis/gas chromatography/mass spectrometry in the analysis of glycated poly-L-lysine, Organic Mass Spectrometry 27 (1992), 183-187.

[38] J.N. Liang, Circular dichroism of the non-enzymatic browning products of poly-L-lysineand albumin, International Journal of Biological Macromolecules 12 (1990), 273-277.

[39] S. Ligier, P.R. Fortin and M.M. Newkirk, A new antibody in rheumatoid arthritis targeting glycated IgG: IgM anti-IgGAGE, British Journal of Rheumatology 37 (1998), 1307-1314.

[40] M. Lucey, M.M. Newkirk, C. Neville, K. Lepage and P.R. Fortin, Association between IgM response to IgG damaged by glyoxidation and disease activity in rheumatoid arthritis, Journal of Rheumatology 27 (2000), 319-323.

[41] T. Menini, A. Gugliucci, Y.K. Sodahlon, A.J.C. Stahl, J.F. Blickle and J.M. Brogard, Glycated immunoglobulin $\mathrm{M}$ in diabetic patients, Annals of Biological Chemistry 50 (1993), 887-891.

[42] J.A. Miller, E. Gravelles and F.H. Bunn, Nonenzymatic glycosylation of erythrocyte membrane proteins. Relevance to diabetes, Journal of Clinical Investigation 65 (1980), 896-901.

[43] T. Miyata, N. Ishiguro, Y. Yasuda, T. Ito, M. Nangaku, H. Iwata and K. Kurukawa, Increased pentosidine, an AGE, in plasma and synovial fluid from patients with rheumatoid arthritis and its relation with inflammatory markers, Biochemical Biophysical Research Communication 244 (1998), 45-49.

[44] T. Miyata, N. Ishikawa and C.Y. De Strihou, Carbonyl stress and diabetic complications, Clinical Chemistry and Laboratory Medicine 41 (2003), 1150-1158.

[45] V.M. Monnier, Nonenzymatic glycosylation, the Maillard reaction and aging process, Journal of Gerontology 45 (1990), B105-B111.

[46] V.M. Monnier, G.T. Mustata, K.L. Biemel, O. Reihl, M.O. Lederer, D. Zhenyu and D.R. Sell, Cross-linking of the extracellular matrix by the Maillard reaction in aging and diabetes, Annals of the New York Academy of Sciences 1043 (2005), 533-544.

[47] V.M. Monnier, D.R. Sell, Z. Dai, I. Nemet, F. Collard and F. Zhang, The role of the Amadori product in complications of diabetes, Annals of the New York Academy of Sciences 1126 (2008), 81-88.

[48] G. Munch, D. Schicktanz, A. Behme, M. Gerlach, P. Riederer, P. Palm et al., Amino acid specificity of glycation and proteinAGE crosslinking reactivities determined with a dipeptide SPOT library, Nature Biotechnology 17 (1999), 1006-1010.

[49] T. Myint, S. Hoshi, T. Ookawara, N. Miyazawa, K. Suzuki and N. Taniguchi, Immunological detection of glycated proteins in normal and streptozotocin-induced diabetic rats using anti hexitol-lysine IgG, Biochimica Biophysica Acta 1271 (1995), 73-79.

[50] R. Nagai, K. Ikeda, T. Higashi, H. Sano, Y. Jinnouchi, Y. Araki et al., Hydroxyl radical mediates $\mathrm{N}^{\varepsilon}$-(carboxymethyl)lysine formation from Amadori product, Biochemical Biophysical Research Communication 234 (1997), 167-172.

[51] M.M. Newkirk, R. Goldbach-Mansky, J. Lee, J. Hoxworth, A. McCoy, C. Yarboro et al., Advanced glycation end-product (AGE)-damaged IgG and IgM autoantibodies to IgG-AGE in patients with early synovitis, Arthritis Research and Therapy 5 (2003), 82-90.

[52] J. Ni, X. Yuan, J. Gu, X. Yue, X. Gu, R.H. Nagaraj and J.W. Crabb, Plasma protein pentosidine and carboxymethyllysine, biomarkers for age-related macular degeneration, Molecular and Cellular Proteomics 8 (2009), 1921-1933.

[53] R. Ramasamy, S.J. Vannucci, S.S.D. Yan, K. Herold, S.F. Yan and A.M. Schmidt, Advanced glycation end products and RAGE: a common thread in aging, diabetes, neurodegeneration, and inflammation, Glycobiology 15(7) (2005), 16R-28R.

[54] M. Ranjan, S. Nayak and B.S. Rao, Immunochemical detection of glycated $\beta$ - and $\gamma$-crystallins in lens and their circulating autoantibodies $(\mathrm{IgG})$ in streptozocin induced diabetic rat, Molecular Vision 12 (2006), 1077-1085.

[55] M. Ranjan, S. Nayak, T. Kosuri and B.S. Rao, Immunochemical detection of glycated lens crystallins and their circulating autoantibodies in human serum during aging, Molecular Vision 14 (2008), 2056-2066.

[56] Z. Rasheed and R. Ali, Reactive oxygen species damaged human serum albumin in patients with type 1 diabetes mellitus: Biochemical and immunological studies, Life Sciences 79 (2006), 2320-2328.

[57] Z. Rasheed, L. Kumar, S. Abbas, I. Prasad, N.A. Ansari and R. Ahmad, Advanced glycation end-products damaged IgG, a target for circulating autoantibodies in patients with type 1 diabetes mellitus, Open Glycoscience 2 (2009), 1-8.

[58] T. Richter, G. Munch, H. Luth, T. Arendt, R. Kientsch-Engel, P. Stahl, D. Fengler and B. Kuha, Immunochemical crossreactivity of antibodies specific for "advanced glycation endproducts" with advanced lipoxidation endproducts", Neurobiology of Aging 26 (2005), 465-474.

[59] C.G. Schalkwijk, N. Chaturvedi, H. Twaafhoven, V.W. Van Hinsbergh and C.D. Stehouwer, Amadori albumin correlates with microvascular complications and precedes nephropathy in type 1 diabetes, European Journal of Clinical Investigation 32 (2002), 500-506.

[60] C.G. Schalkwijk, N. Ligtvoet, H. Twaafhoven, A. Jager, H.G.T. Blaauwgeers, R.O. Schlingemann et al., Amadori albumin in type 1 diabetic patients: correlation with markers of endothelial function, association with diabetic nephropathy and localization in retinal capillaries, Diabetes 48 (1999), 2446-2453.

[61] C.G. Schalkwijk and T. Miyata, Early- and advanced nonenzymatic glycation in diabetic vascular complications: the search for therapeutics, Amino Acids (2010) (doi:10.1007/ s00726-010-0779-9).

[62] E.D. Schleicher, E. Wagner and A.G. Nerlich, Increased accumulation of the glycoxidation product $\mathrm{N}^{\varepsilon_{-}}$ (carboxymethyl)lysine in human tissues in diabetes and aging, Journal of Clinical Investigation 99 (1997), 457-468.

[63] U. Schwarzenbolz, S. Mende and T. Henle, Model studies on protein glycation, Annals of the New York Academy of Sciences 1126 (2008), 248-252.

[64] R.H. Scofield, Autoantibodies as predictors of disease, The Lancet 363 (2004), 1544-1546.

[65] R.D. Semba, S. Bandinelli, K. Sun, J.M. Guralnik and L. Ferrucci, Plasma carboxymethyl-lysine, an advanced glycation endproduct and all-cause and cardiovascular disease mortality in older community dwelling adults, Journal of the American Geriatrics Society 57 (2009), 1874-1880.

[66] J.S. Sjoberg and S. Bulterijs, Characteristics, formation, and pathophysiology of glucosepane: a major protein cross-link, Rejuvenation Research 12 (2009), 137-148.

[67] N. Shaklai, R.L. Garlick and F.H. Bunn, Nonenzymatic glycosylation of human serum albumin alters its conformation and function, Journal of Biological Chemistry 259 (1984), 3812-3817. 
[68] R. Shibayama, N. Araki, R. Nagai and R. Horiuchi, Autoantibody against $\mathrm{N}^{\varepsilon}$-(Carboxymethyl)lysine: An advanced glycation endproduct of the Maillard reaction 48 (1999), 1842 1849.

[69] H.M. Sims, A.L. Birdwell, K.E. O'Reilley, A. Bwashi and B.D. Wing, Inhibition of protein glycation with varying concentrations of lysine, The FASEB Journal 22 (2008), 1123.15.

[70] J.H. Sohn, J.O. So, H. Kim, E.J. Nam, H.J. Ha, Y.H. Kim and I. Mook-Jung, Reduced serum level of antibodies against amyloid beta peptide is associated with aging in Tg2576 mice, Biochemical Biophysical Research Communication 361 (2007), 800-804.

[71] J.V. Stevens, C.A. Rouzer, V.M. Monnier and V.M. Cerami, Diabetic cataract formation: potential role of glycosylation of lens crystallins, Proceedings of the National Academy of Sciences USA 75 (1978), 2918-2922.

[72] C.E. Taplin and J.M. Barker, Autoantibodies in type 1 diabetes, Autoimmunity 41 (2008), 11-18.

[73] P.J. Thornalley, S. Battah and S. Ahmed, Quantitative screening of advanced glycation endproducts in cellular and extracellular proteins by tandem mass spectrometry, Biochemical Journal 375 (2003), 581-592.

[74] P.J. Thornalley and N. Rabbani, Therapy: Vitamin B(6), B(9) and $\mathrm{B}(12)$ in diabetic nephropathy-beware, Nature Review Endocrinology 6 (2010), 477-478.

[75] S.M. Trigwell, P.M. Radford, S.R. Page, A.C. Loweth, R.F.L. James and N.G. Morgan, Islet glutamic acid decarboxylase modified by reactive oxygen species is recognized by anti- bodies from patients with type 1 diabetes mellitus, Clin Exp Immunol 126 (2001), 242-249.

[76] Z. Turk, Glycation and complications of diabetes, Diabetologia Croatica 30 (2001), 49-54.

[77] Z. Turk, S. Ljubic, N. Turk and B. Benko, Detection of autoantibodies against advanced glycation endproducts and AGEimmune complexes in serum of patients with diabetes mellitus, Clinica Chimica Acta 303 (2001), 105-115.

[78] P. Ulrich and A. Cerami, Protein glycation, diabetes and aging, Recent Progress in Hormone Research 56 (2001), 1-22.

[79] J.W.J. Van Heijst, H.W.M. Niessen, K. Hoekman and C.G. Schalkwijk, Advanced glycation endproducts in human tissues, Annals of the New York Academy of Sciences 1043 (2005), 725-733.

[80] N.G. Watkins, S.R. Thorpe and J.W. Baynes, Glycation of amino groups in protein, Journal of Biological Chemistry $\mathbf{2 6 0}$ (1985), 10629-10636.

[81] M.E. Weksler and M.E. Goodhardt, Do age-associated changes in 'physiologic' autoantibodies contribute to infection, atherosclerosis, and Alzheimer's disease? Experimental Gerontology 37 (2002), 971-979.

[82] G.T. Wondrak, D. Cervantes-Laurean, E.L. Jacobson and M.K. Jacobson, Histone carbonylation in vivo and in vitro, Biochemical Journal 351 (2000), 769-777.

[83] D. Yin and D. Chen, The essential mechanisms of aging: Irreparable damage accumulation of biochemical side-reactions, Experimental Gerontology 40 (2005), 455-465. 


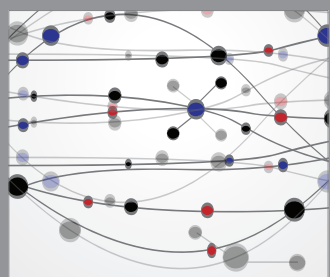

The Scientific World Journal
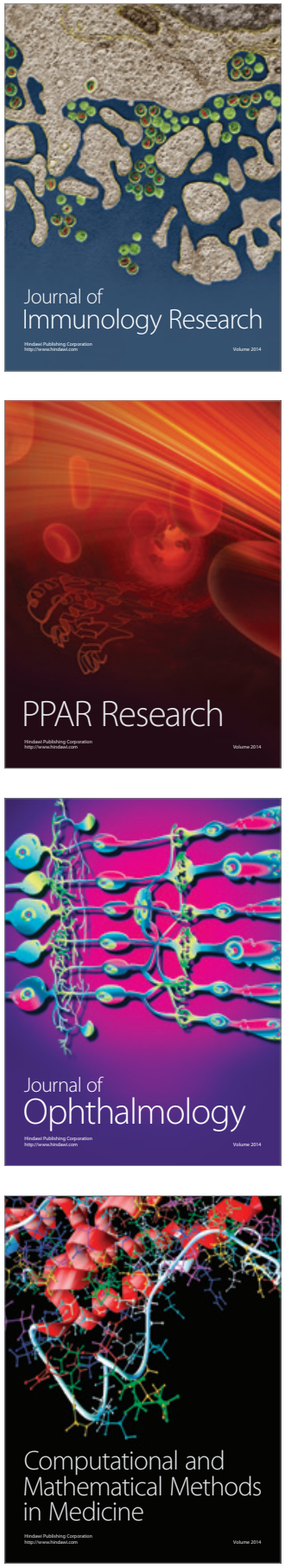

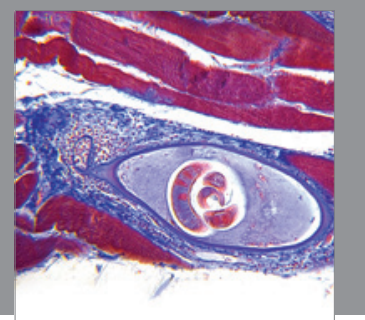

Gastroenterology

Research and Practice
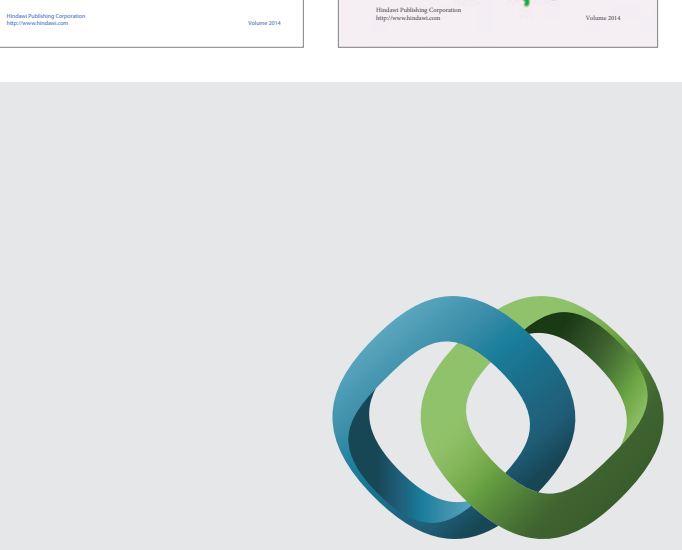

\section{Hindawi}

Submit your manuscripts at

http://www.hindawi.com
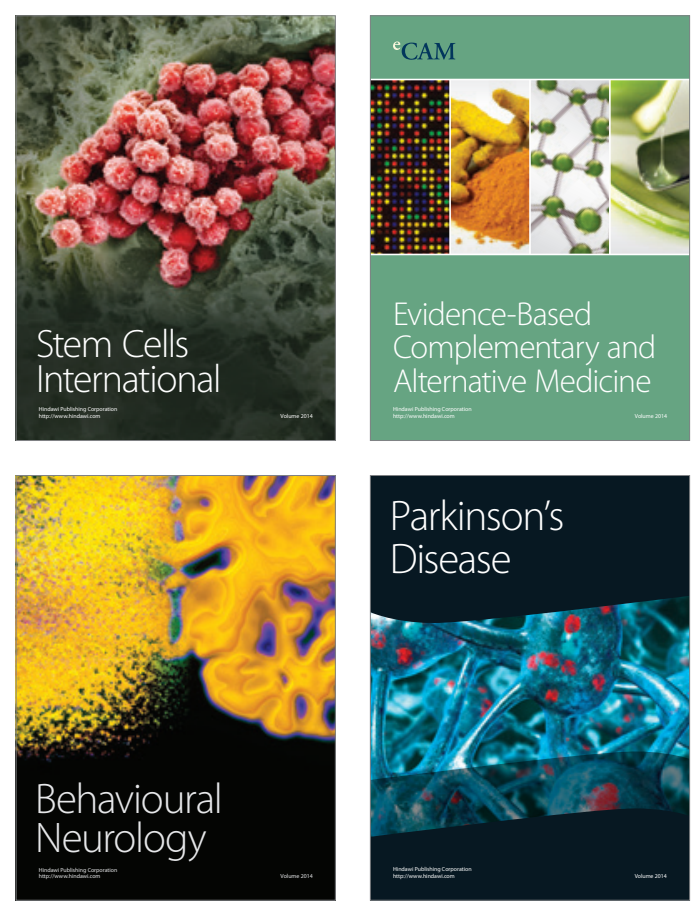

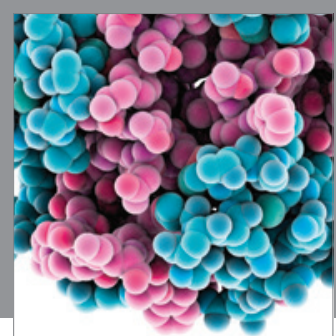

Journal of
Diabetes Research

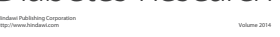

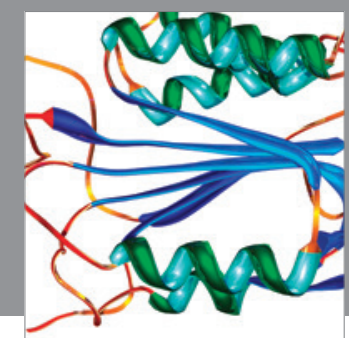

Disease Markers
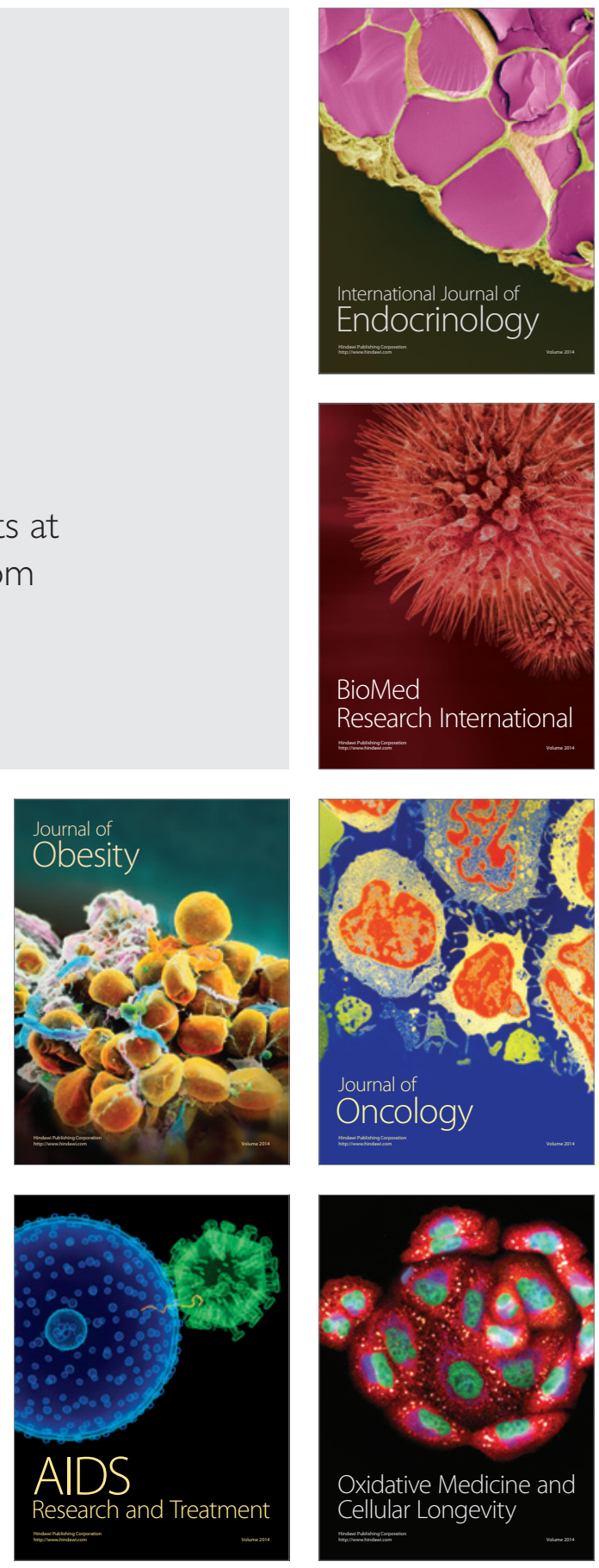